\title{
THEOSOPHICAL SOCIETY IN GLOBALIZATION PERSPECTIVE
}

\author{
Fardana Khirzul Haq \\ UNIDA Gontor
}

Email: fardanakhirzulhaq@unida.ac.id.

\begin{abstract}
Modernistic globalization with empirical and rational methods has given its significant advancement to Western society. The advancement, however, eroded the spiritual values, especially Christianity, that for almost ten centuries championed the Europeans minds. Spiritualism or religions is regarded as ancient and have no value in the development of society. Blavatsky and Olcott felt that the rapid growth of modernistic globalization has to be equaled by spiritualism. Therefore, they founded an organization with goals to reestablish spiritual and traditional values that have been long lost from Western society. In order to challenge the modernistic globalization, Theosophical Society used spiritualistic globalization. The organization is quite successful and gains lots of followers from renowned people. Olcott, the first president, is an experienced media person. Newspapers and magazines are the two main components that brought the organization to its fame.
\end{abstract}

\section{Keywords: Theosophy, Theosophical Society, Sociology}

\section{A. Introduction}

Western civilization has become the civilization regarded to be the most advanced and often seen as the barometer of advancement by its Eastern counterpart. ${ }^{1}$ Modernism in life and globalization in science and technology have been developed vastly in the West. Rationalism, empiricism, and positivism have replaced the influence of religious dogma in the social life of Western society. God that had become the centre of everything, marked by the Catholic Church's rule from the 4th-14th century, has been replaced with a scientific perspective. This shift, eventually, occurred in all aspects of Western society, including its religious and social aspects.

1 Hamid Fahmy Zarkasyi, Liberalisasi Pemikiran Islam (Ponorogo: Centre for Islamic and Occidental Studies, 2008) p. 5 
Before that event, the Catholic Church was the dominant institution that ruled over Western society. The domination of the Catholic Church was started in 476, following the demise of the Western Roman Empire. All aspects of Western society were under the influence of the church. The church provided spiritual answers regarding the concept of life and death to the mass. Through this influence, the church started to replace the local tradition of Western society. ${ }^{2}$ Hutton Webster, in his book, explained that the church focused its activities on worship, charity, and promoting peace. $^{3}$

This period was known as the Dark Age. During this age, Europeans were restrained within the Catholic Church. Constant abuse their power, proclamation as the Christ representative that gives the highest authority, and the inability to be wrong are the negative sides of the church. Scientists were obliged to be submissive to the church's dogma and authority. Copernicus (1473-1543) and Galileo Galilei (1546-1642) are examples of scientists that went against the church that cost them exile. ${ }^{4}$

The rebellion made by the scientists was soon followed by reformation within the Catholic Church. Protestant Reformation diminished the influence of the church and created disharmony between the Church and European society. Eventually, radical views started to emerge, questioning the legitimacy of the church, all aspects related to its theology, hierarchy, history, and activities that were regarded to be deviant from Christianity. ${ }^{5}$

After the end of the church's influence, Europe had a trauma towards all religions, not only Christianity. They started to incline towards philosophical

${ }^{2}$ Adian Husaini, Wajah Peradaban Barat: Dari Hegemoni Kristen ke Dominasi Sekular-Liberal (Jakarta: Gema Insani Press, 2005) p. 30-33.

\footnotetext{
${ }^{3}$ Hutton Webster, World History (Boston: D.C. Heath \& Co., Publisher, 1921) p. 204-205.

${ }^{4}$ Adian Husaini, Wajah Peradaban Barat, p. 38-48.

${ }^{5}$ Graham E. Fuller, Apa Jadinya Dunia Tanpa Islam (Bandung: Mizan, 2014) p. 152-53.
} 
science. This inclination brought them to the birth of the Renaissance in Italy, the French Revolution, and the Industrial Revolution in England. During this period, religions were abandoned while technology and industry were developed. ${ }^{6}$ Globalization is the process that pushes other nations and society to accept the modern culture and tradition that has been developed in the West.

The shift from God to science has influenced the soul of Western society. They feel hollow and empty. Spiritual and traditional values have been lost. Modernism that replaced the two values is not the answer to their spiritual problems. The idea of returning to the original values have been reverberating and gave birth to the theosophical spiritual understanding that has been developed globally.

Blavatsky is one of the proponents that encourage the return to spiritualism and theosophy that have been long lost from the West. ${ }^{7}$ She is one of the founders of the Theosophical Society, an organization that has been developing the theosophical and traditional spirituality and the values lost in the West. How is the theosophical society in the Globalization perspective? What is the approach used to introduce it? What are the challenges in the global and local spread of this movement? What is the future of this movement?

\section{B. Discussion}

\section{Globalization}

Since the 1970s, media, and information have been developed rapidly, the previous one-for-one media such as printed media and telegraph have been developed into one-for-all kinds such as Radio. It was developed further into all-for-all kinds with the rapid growth of social media. This development of

\footnotetext{
${ }^{6}$ Hamid Fahmy Zarkasyi, Liberalisasi Pemikiran Islam, p. 7-9.

${ }^{7}$ H.P. Blavatsky, The Theosophical Movement (California: Cunninghm Press, 1951) p. 12.
} 
media has enabled the spread of all kinds of social beliefs in all forms that could be easily and quickly accessed. ${ }^{8}$

Globalization of contemporary media occurs if the activity has specific criteria as follows:

a. It occurs globally and comprehensively, not only limited to national or regional scope but international.

b. It runs on a global scale.

c. It involves the interdependence of different activities across the globe.

d. It often involves media and technology that made it possible to be completed with rapid communication. ${ }^{9}$

Globalization marked its beginning with the nullification of the Bretton Woods agreement by Richard Nixon, the President of the United States. Through this nullification, the wave of globalization cannot be held for any longer, and it influenced almost all aspects, starting from the economy, business, trade, and communication. Some economic analysts consider this event as the beginning of neoliberalism.

Another hallmark is the September $11^{\text {th }}$ incident. The attack that surprised the world was specifically directed to a target that has always been highlighted by media. From this incident, the term terrorism emerged and started to be known as Global War. Fear and threat spread across the globe, partially because of the role of media.

The term global is equivalent to the term universal. However, in certain definitions, the two terms are not similar. On the one hand, the term universal

${ }^{8}$ Gill Branston and Roy Stafford, The Media Student's Book Fifth Edition (New York: Routledge, 2010) p. 139-140.

${ }^{9}$ Gill Branston and Roy Stafford, The Media Student's Book Fifth Edition, p. 140. 
is not bound to time and space. On the other hand, global is a pattern or trend restricted only to a certain time. The effect of globalization eventually drove powerful and established nations to push their way of life to other nations. The spread of the superior way of life, then, sidelined the traditional and local ones, especially in media and culture. ${ }^{10}$

Globalization is mostly not a problem. The problem is its tendency to favor specific groups over another. Several factors brought the United States to have immense power and influence. First, the United States dominates the advertisements and promotion, especially renowned media that have been under their influence. Second, the spread of the advertisements and brands, that funded the media nurtures the obsession from the audience to follow the promoted lifestyle. ${ }^{11}$

Before the arrival of the United States and other media, the third world nations have already experienced the golden age of their culture, authentic traditions, and cultural heritage. Soon, they were corrupted with foreign and alien values. Critics have warned that this phenomenon has a risk of pushing weaker nations and return them to their pre-colonial traditions. Sometimes a culture often called as custom, which is a mixture of advanced culture and ancestral heritage, undergoes a long, dark process, and even a process of assimilation.

Globalization has never experienced a smooth process of homogeneity that brings the world to a shared point of view. Naturally, textual cultures experienced exchanges among them, language, and cultural heritage that have become enriched and sophisticated and enable them to have such change. Globalization, however, is not necessarily the Western expansion of other parts of the world. ${ }^{12}$

${ }^{10}$ Gill Branston and Roy Stafford, The Media Student's Book Fifth Edition, p. 144-145.

${ }^{11}$ Gill Branston and Roy Stafford, The Media Student's Book Fifth Edition, p. 145.

12 Gill Branston and Roy Stafford, The Media Student's Book Fifth Edition, p. 147-148. 
The middle road that can be taken is "Glocal." It aims to keep consumers developed and fulfill their contemporary capitalistic needs within the boundary of local customs and culture. Globalization often refers to a particular stage of neoliberalism or global consumer capitalism. ${ }^{13}$

After the US-led Western domination, the development of globalization started to show substantial Chinese roles. Although certain things still need to be improved, China is sometimes seen to dominate the current globalization wave. Some notes on China:

a. Despite being a productive nation, the Chinese do not have a renowned brand that is globally acknowledged. China is notorious for repackaging and reduplicating global brands.

b. The Chinese government is weak on soft power, a political concept that focused on diplomatic problem solving instead of using force. Most of the Chinese residents cannot speak foreign languages which became one of their problems.

c. Chinese global power is not rooted in their influential imperial history. Instead, it is from their capacity to produce cheap and readily available goods in the Western market through exploitation and economic scale policy.

d. The emergence of another Asian power in globalization, especially India.

e. Chinese government tends to neglect environmental issues that are harmful to the earth. ${ }^{14}$

Several analysts consider that globalization cannot replace the local values or national, religious, legal, media institution boundaries. Identity could be

${ }^{13}$ Gill Branston and Roy Stafford, The Media Student's Book Fifth Edition, p. 149.

${ }^{14}$ Gill Branston and Roy Stafford, The Media Student's Book Fifth Edition, p. 150-153. 
changed, but it cannot be erased by globalization. The definition of the term global is comprised of:

a. Area, for example, the territory of the developed capitalist consumers such as North America, Europe, and East Asia.

b. Language, as inherited from colonial powers such as Spanish and Latin.

c. Religion and culture, for example, Islam in the Middle East.

d. Technological factors. ${ }^{15}$

From the conceptual definition of globalization above, it can be concluded that globalization is unable to uniform one perception or shared perspective globally. Forcefully enforcing modernity could scrape local cultures away. However, it is almost impossible to do so. Globalization is focused on the economy, technology, and ideology, without acknowledging the existing local values. This materialistic mindset has ruled over powerful nations such as the United States and China. Therefore, a new movement is needed to resuscitate human spirituality and morality to prevent environmental damages.

Blavatsky and the Theosophical Society has the vision to balance these arguments. So, spiritual values can be protected alongside the development that could be achieved.

\section{Conceptual Methodology}

Etymologically, the word theosophy is originated from the word theos, meaning God and sophos, meaning wisdom. ${ }^{16}$ According to Rudolf Steiner,

15 Gill Branston dan Roy Stafford, The Media Student's Book Third Edition (New York: Routledge, 2003) Hal. 419.

${ }^{16}$ http://www.etymonline.com/index.php?allowed_in_frame=0\&search=theosophy 
theosophy is the divine wisdom that connects humans with God and reveals humans' identity and explains humans' final objective. ${ }^{17}$

Essentially, theosophy exists within the teachings of all religions. It means that theosophy is a global understanding that emerges from religions. In Indian cultures, it is known as Brahmavidya or Sanatana Dharma. It is Kabbalah in Jewish traditions, Tao Hsueh in Chinese traditions, Sufism in Islamic traditions, and in Christianity, it is commonly called as Prisca Thelogia. Generally, the term commonly used across religion is Perennial Philosophy. ${ }^{18}$

In her work, Blavatsky explains that theosophy is not a religion; instead, theosophy is the knowledge of the Divine wisdom. Specifically, this knowledge is not the knowledge of the Divine but the knowledge that has the nature of and originated from divine values. ${ }^{19}$

In her other work, she explains that essentially the world does not need any sectarian church, Buddha, Jesus, Muhammad, Swedenborg ${ }^{20}$, or Calvin ${ }^{21}$. Instead, what the world needs is One Truth, one church within the human that can only be achieved by those who have found the way, those with a pure heart to see the Divine. From the esoteric perspective, she saw Christianity as pure disbelief, and Catholicism, with its worship amulets, is far more worst and destructive than Hinduism on its idol worshipping. The eternal conflict between

${ }^{17}$ Rudolf Steiner, Theosophy, An Introduction to the Supersensible Knowledge of the World and the Destination of Man (Dornach, Rudolf Steiner Press:2011) Hal. 5.

18 John Algeo, Theosophy: An Introductory Study Course (Wheaton: Theosophical Society in America, 2007) p. 8.

19 H.P. Blavatsky, The Key to Theosophy (Pasadena: Theosophical University Press Online Edition, 1889) p. 1.

20 A Swedish scientist, philosopher, Christian mystic, and theologian. Swedenborg had a productive career as an inventor and scientist. He claimed to be tasked by God to write heavenly doctrines to reform the Christianity.

${ }^{21}$ Calvin is a French theologian during the Protestant Reformation. His name is cemented within the Christian theology system as Calvinism. 
Christianity, Judaism, Brahmanism, Paganism, Buddhism, is originated from the truth that is based on their belief system. Therefore, a global universal truth that can be accepted by all religions is needed. ${ }^{22}$

From the statement above, it can be noted that Blavatsky has put the esoteric perspective of all existing as the most important thing. Antoine Faivre has explained the characteristics of religious beliefs, which can be called as Western esotericism. According to Faivre, these characteristics are the correspondence between living things, either macrocosm or microcosm, a complex living nature, plural, and hierarchical, imaginations, and meditations as spiritual forms and symbols, and experience of soul transmutation through initiation. These are the characteristics of the Theosophical Society that has the values of Western Esotericism. ${ }^{23}$

Blavatsky believes that individual evolution is an eternal, continuous process through countless of lives. This continuity is made possible through reincarnation, which is the transfer of the spirit, soul, and mind from one vessel to another. A complement to the reincarnation is power, known as the law of cause and effect, where rebirth is the first step of the future and determine the quality of the being. ${ }^{24}$

There are three main objects studied within the Theosophical Society:

a. Universal brotherhood without differentiating between race, belief, gender, social caste, or colours.

b. The study of wisdom, religions, philosophy, and science.

c. The law of nature and latent strength of humanity.

${ }^{22}$ H.P. Blavatsky, Theosophy: An Introduction (Blavatsky Study Center, 2012) p. 84-85.

23 Jeffrey D. Lavoie, The Theosophical Society: The History of a Spiritualist Movement (Florida: Brown Walker Press, 2012) p. 7.

${ }^{24}$ James A. Santucci, Theosophy and the Theosophical Societies (Theosophy Forward, 2013) p. 27. 
Theosophical Society aims to build a shared understanding of various things, in order to create global, universal truth.

Theosophical Society was rapidly developed during the time of Annie Besant. She wrote the tenets of Theosophical Society that are constituted of four main pillars of reality alongside the objectives in achieving The Ancient Wisdom. Those four pillars of reality are:

a. Oneness of God; God is universal and global, the source of the existed and future laws, the One who gives help but does not need one, the First and without equal, $\mathrm{He}$ is the only being all religions have.

b. Trinity is the divine manifestation; It is the highest wisdom and can be understood by humans.

c. The level of beings; Besides humans, there are also other beings created by God, such as angels, demons, and others.

d. Global and universal brotherhood; Despite the differences essentially, humans are of one soul and blood. Therefore, the brotherhood is not about the shared similarity but to complete each other. $^{25}$

The unity of religion is inevitable within this teaching. The presumption that God is an Absolute Being with all His various creations is the result of the emanation of the All-Powerful Being. This teaching puts the truth as the most important as in their motto: There is No Religion or Law Higher Than Truth. ${ }^{26}$

\section{Case Study}

${ }^{25}$ Annie Besant, "Theosophical Society" in James Hastings, The Encyclopedia of Religion and Ethics Vol. 12. (London: Morrison and Gibb Limited, 1921) p. 300-303.

${ }^{26}$ H.P. Blavatsky, The Secret Doctrine (Pasadena, Theosophical University Press Online Edition: 1888) p. 11. 
The theosophical teachings were started to be known when Helena Petrovna Blavatsky and Colonel Henry S. Olcott established the Theosophical Society. ${ }^{27}$ This society was established on November $17^{\text {th }}, 1875$.

Helena Petrovna Blavatsky is a Russian who later received a United States citizenship through the naturalization process. She came from a Russian aristocratic family from her maternal line and a Russian military officer from his paternal line. Her mother is a novelist and often dubbed as the Russian George Sand ${ }^{28}$ because of her interest in social protests. Blavatsky was married at a young age, but she had to abandon the pleasure of upper-class life to explore the life mystery by embarking on world travels in search of wisdom. She finally arrived and learned from several teachers or gurus. Finally, she became the founder of an organization with goals to serve and spread wisdom for humanity. ${ }^{29}$

Henry Steel Olcott is an American lawyer who served his country during the American Civil War as an inspector. His successful duty in revealing fraud in the supply procurement granted him the nickname, Colonel Olcott. He later became a part of a commission tasked to investigate the assassination of President Lincoln. Olcott has a very long, successful career, including as an editor for a publishing house focused on sugar cane crops and as an author of American history books. He is a freelance writer for a New York-based newspaper. In the $19^{\text {th }}$ century, he started to take an interest in spiritualism (contacts with the dead by mediation). At that time, a spiritual phenomenon occurred in a barn in Vermont. He went to Vermont to write a story about the

\footnotetext{
${ }^{27}$ Anis Malik Thoha, Tren Pluralisme Agama (Jakarta: Gema Insani, 2005) p. 100-102.

${ }^{28}$ A French novelist, better known for his criticism in his novels.

${ }^{29}$ John Algeo, Theosophy: An Introductory Study Course, p. 17.
} 
phenomenon, and he eventually met Blavatsky, who also came to witness the phenomenon. ${ }^{30}$

From this meeting, Blavatsky and Olcott were often engaged in esoteric and exoteric discussions. When they returned to New York, their discussion became more intense, and they decided to found a social community. On September $7^{\text {th }}, 1875$, Olcott submitted a proposal on their new organization. The name Theosophical Society was later selected as the name of the organization on September $13^{\text {th }}, 1875$. Two months later, on November $17^{\text {th }}, 1875$, the organization was officially formed, with the Olcott acted as the president, and Blavatsky acted the corresponding secretary. In addition to them, George Henry Felt and Seth Pancoast acted as the vice president and William Quan Judge as the advisor. ${ }^{31}$

Media has a vital role in the spread of this movement. Newspapers started to publish them, especially when they help the first cremation procession in the United States. In order to deepen and spread the movement, Blavatsky and Olcott went to India and Ceylon. A few years later, they founded their first international office in Adyar, India. ${ }^{32}$ Besides newspapers, the organization also published magazines. Their first magazine was published in October 1879, entitled Theosophist. Two publications, Adyar Newsletter and Adyar Bulletin Quest and Messenger, were published soon after in the United States. Several journals were also published and distributed to 51 international offices across the globe. The organization also have their own publishing house named Theosophical University Press. ${ }^{33}$

\footnotetext{
30 John Algeo, Theosophy: An Introductory Study Course, p. 17-18.

31 James A. Santucci, Theosophy and the Theosophical Societies, p. 5.

32 John Algeo, Theosophy: An Introductory Study Course, p. 18.

33 James A. Santucci, Theosophy and the Theosophical Societies, p. 39.
} 
Annie Besant, a British social reformist and renowned orator, became the successor of Blavatsky as the leader of Theosophical Society after Blavatsky's demise in 1891. In 1907, Besant followed Olcott's step as the international president of the organization. Besant learned theosophy from Krishnamurti, an Indian philosopher, and independent guru. Besant was remembered in India as an education lawyer and promotor of house regulation. She became the first female and non-Indian to be selected as the president of the National Congress of India. Following Besant, the international president of the Theosophical Society, including George Arundale and John Coats from the United Kingdom, C. Jinarajadasa from Ceylon, and Sri Ram and Radha Burnier from India. ${ }^{34}$

Theosophical Society is also influencing and funded by prominent individuals, including Abner Doubleday (inventor), Thomas Edison (inventor), Frank Baum (writer), William Butler Yeats (poet), Piet Mondrian (abstract painter), Alexander Scriabin (composer), Mohandas Gandhi (anti-colonial nationalist), and Nehru (Indian prime minister). Some national leaders are also influenced by theosophy, some of them even engaged more than others, including James Joyce, D.H. Lawrence, Maria Montessori, and Wassily Kandinsky. The role of theosophy has shaped the thoughts of the twentieth century. ${ }^{35}$

In the United States, the Theosophical Society has its office in Wheaton, Illinois, in an area named after Olcott, the first chairman of the Society. The organization still exists today with Tim Boyd as the president and Chittaranjam Satapathy and Marja Artamaa, respectively, as the vice-president and the secretary. ${ }^{36}$

\footnotetext{
${ }^{34}$ John Algeo, Theosophy: An Introductory Study Course, p. 19.

${ }^{35}$ John Algeo, Theosophy: An Introductory Study Course, p. 19.

${ }^{36} \mathrm{http}: / /$ www.ts-adyar.org/content/international-officers
} 


\section{Analysis}

Theosophical Society has an approach with three main objects considered to be capable of uniting the perspective globally. Those three objects are brotherhood, wisdom or spiritualism, and the law of nature. This organization has tried to reject the modernistic globalization that pronounces science as is the place where science is exclusively stored (empiric and rationalist). This organization has remained on its tenets with the argument that religion or spirituality has its dimension of truth that is different from science. ${ }^{37}$

In its spread, Theosophical Society used spiritualistic globalization since its foundation. The strength of this organization is in its economy, the influence of its members, and the power of media. Principally, Theosophical Society intended to challenge the modernistic globalization with spiritualistic globalization through the use of soft power.

This organization has been widely criticized. F. Max Muller criticized Blavatsky for her concept of religious belief syncretism that blurs those religions. Muller also argued that the esoteric concept of divinity proposed by Blavatsky has no firm foundation. ${ }^{38}$

Regarding the first object of the organization that is the global brotherhood, it has a significant role in Islam. In al-Quran it was stated that initially, humankind was of one community:

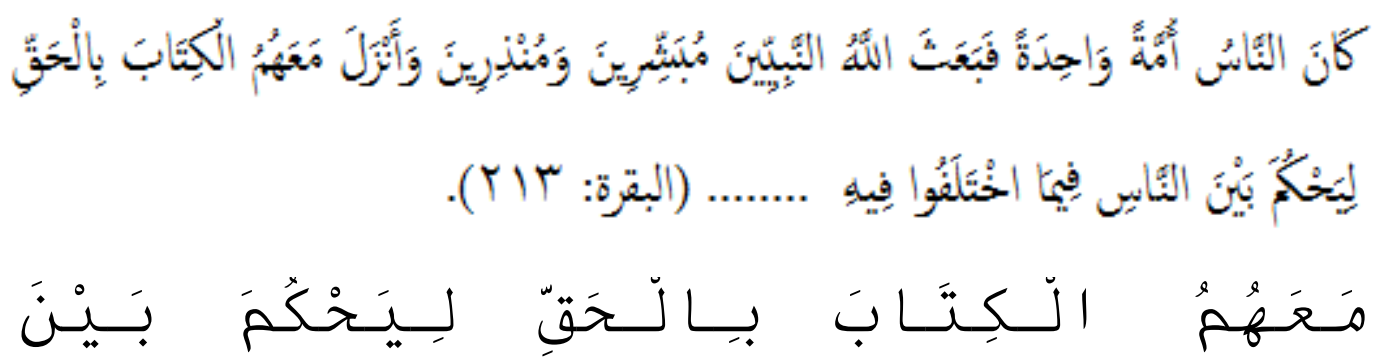

${ }^{37}$ John D. Caputo, On Religion (New York: Routledge, 2001) p. 110-111.

38 Joy Dixon, Divine Feminine, Theosophy and Feminism in England (Maryland: The Johns Hopkins University Press, 2001) p. 6. 


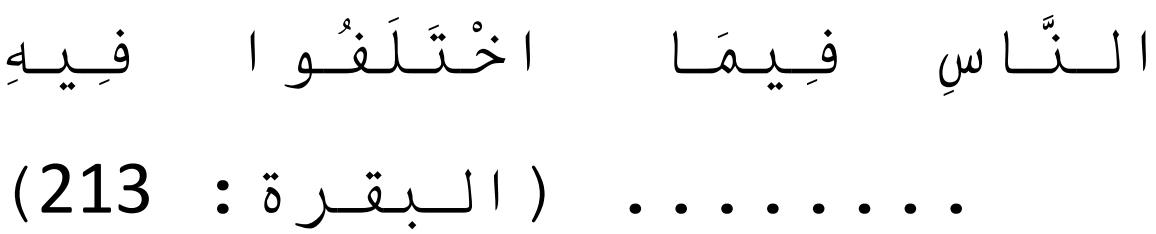

Mankind was [of] one religion [before their deviation]; then Allah sent the prophets as bringers of good tidings and warners and sent down with them the Scripture in truth to judge between the people concerning that in which they differed.

In his Tafsir, Ibn Kathir explained that initially, humankind was united in one community, and Sharia was the means to unify them. When disputes emerged among them, God will send His prophets to resolve the disputes. ${ }^{39}$ On this matter, the globalization of Sharia once existed in the world. The word ummah is a universal and global term, not only restricted to the Muslim ummah, but also all communities and groups. ${ }^{40}$ The Madinah Charter is proof that the Sharia is capable of unifying the ummah, not only the Muslim ummah. ${ }^{41}$

A brotherhood that is based on the Sharia is among the ways to unify society. Theosophical Society neglected this and branded it as an individual domain or exoteric. Instead, the Society creates brotherhood on the esoteric domain where everyone is equal. If the modernists saw a brotherhood merely as a relationship of humanity, an inevitability within a community, then they saw it because of the spiritual values that trigger them. Islam, on the other hand, saw it more than that because brotherhood is the manifestation of faith, a command from God, and an act of worship, as stated in verse:

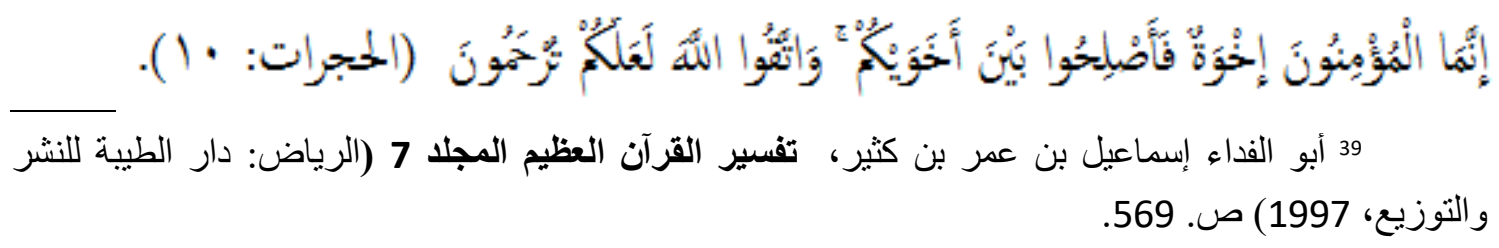

40 Isma'il Raji al-Faruqi, Al-Tawhid: It's Implications for Thought and Life (Virginia: The International Institute of Islamic Thought, 1992) p. 103-104.

${ }^{41}$ Anis Malik Thoha, Tren Pluralisme Agama, p. 205. 
And if two factions among the believers should fight, then make settlement between the two. But if one of them oppresses the other, then fight against the one that oppresses until it returns to the ordinance of Allah.

And in the Hadith:
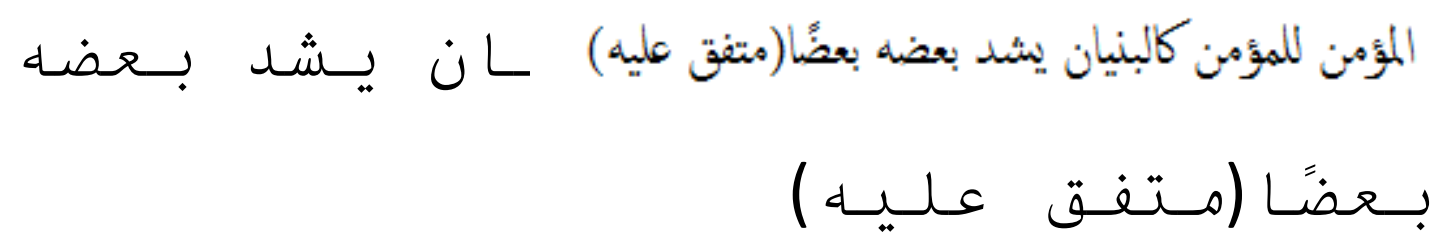

The believers are one building. With them strengthening one another.

It can be concluded that the efforts made by the Theosophical Society to challenge the modernistic globalization by spreading the idea of global brotherhood are similar efforts that have been successfully implemented for a long time. However, their concept prioritizes the esoteric domain as the differentiating aspect in contrast with Islam that put both exoteric and esoteric domains as its priority. ${ }^{42}$ In Islam, Sharia is an essential aspect of unifying and creating a global brotherhood. However, if it is undesirable or not possible to implement the Sharia, then at least the founded brotherhood is not contradictory, externally and internally, to the Islamic Sharia.

The second object of the organization is spiritual wisdom. Spiritualism and traditionalism are the proper means to challenge modernistic globalization. Traditionalism is a term that, according to Guenon, a disciple of Blavatsky, is the values possessed by customs, cultures, norms, dogmas, and principles inherited from religions or tribes, often called as normal or traditional. ${ }^{43}$

${ }^{42}$ Adnin Armas, Gagasan Frithjof Schuon tentang Titik-Temu Agama-agama in Adnin Armas (Ed) Pluralisme Agama: Telaah Kritis Cendekiawan Muslim (Jakarta: Institute for the Study of Islamic Thought and Civilization, 2013) p. 15.

\footnotetext{
${ }^{43}$ Rene Guenon, The Crisis of the Modern World (Hillsdale: Sophiaperennis, 1942) p. 21.
} 
The dynamics of the modern age has led to the rise of the traditionalism and wisdom long lost from Western society. The absence of those values led to the common practice of natural exploitation and human exploitation. ${ }^{44}$

From Islamic perspective, it has been mentioned in Q.S. Ar-Rum, verse 41:
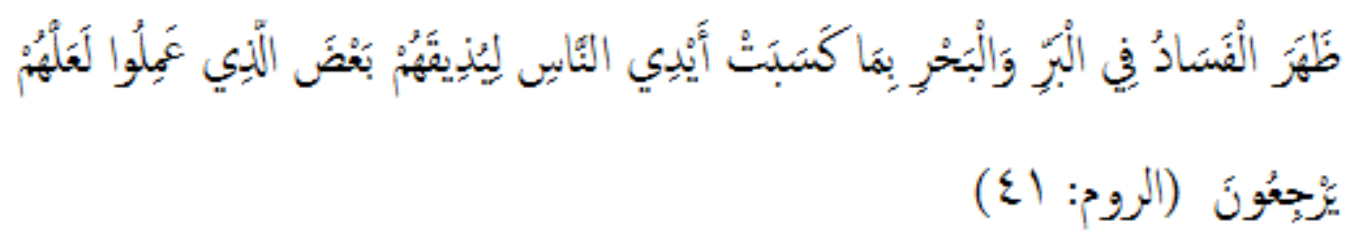
the nanas of people nave earnea so He may let them taste part of Ithe consequence of] what they have done that perhaps they will return [to righteousness].

According to Tafsir Ibn Kathir, this verse explained that the destruction both in urban and rural areas are the result of human exploitation, because of their insubordination towards God. ${ }^{45}$ Honouring nature, both animals and plants, is among the main principles in theosophy. By acknowledging that human, as a creation, is equal to animals and plants, then ethics will emerge. ${ }^{46}$ This is what the traditionalists want to achieve and the resistance against modernistic globalization.

The concept of spiritualism that covers this traditionalism brought perennial philosophy. Islamic thinkers such as Guenon, Schuon, and Nasr argued that religion is the exoteric domain that eventually shifts toward the esoteric domain with one God. The organization, however, is freer, where all concepts related to spirituality, either it is magic or sorcery, is called spiritualism. Eventually, the truth that they seek is relative in nature, depends highly on the spiritual teaching they follow. This perennial philosophy is a threat. First, all spiritual traditions will have equal value because they all

${ }^{44}$ Gill Branston dan Roy Stafford, The Media Student's Book Fifth Edition, p. 153.

$$
45 \text { أبو الفداء إسماعبل بن عمر بن كثير، تفسير القرآن العظيم المجلد 6، ص. 319-320. }
$$

${ }^{46}$ John Algeo, Theosophy: An Introductory Study Course, p. 27. 
directed towards a single entity. Second, all the traditions have the concept of salvation that must be equally justified. Third, there will be no permanent traditions as they become open and subject to change. ${ }^{47}$

The idea of religion without religions then emerged as an effort to curb the religious differences. Ethics toward God and humans became more important than the religion itself. ${ }^{48}$ Sikhism in India, Baha'ism in Iran, Cuadaism in Vietnam, or mysticism in Indonesia are the example of teachings that adopt spiritualism and abandon those that are contradicting, and that is their doctrine. ${ }^{49}$

Islam is a way of life, a complete process of life, and it has values that need to be protected. Everyone cannot interpret the Quranic verses without studying it textually and contextually. ${ }^{50}$ If the perennial philosophy develops, eventually, it will erode those values. Everything will be regarded as relative, strictly a path, and not as the goal. The truth of religion will only apply according to the global and plural understanding of society, and no longer based on al-Quran and Hadith. ${ }^{51}$

Regarding the second object, traditional globalization is beneficial in developing and raising the awareness of human ethics and demeanors. On the other side, however, blurring the religious teachings and regarded them merely

${ }^{47}$ Syamsuddin Arif, Orientalis dan Diabolisme Pemikiran (Jakarta: Gema Insani, 2008) p. 82-83. Lihat Peter Byrne, Prolegomena to Religious Pluralism.

48 John D. Caputo, On Religion, p. 114.

${ }^{49}$ Syamsuddin Arif, Orientalis dan Diabolisme Pemikiran (Jakarta: Gema Insani, 2008) p. 82

50 Andi Faisal Bakti, The Role of Islamic Media in The Globalization Era: Between Religious Principles and Values of Globalization, The Challenges and The Opportunities, presented in The Second International Conference on Islamic Media December 13-15 2011 in Universitas Pancasila, p.2. or the works of John L. Esposito, Hasan Hanafi dan Nasr Abu Zayd.

${ }^{51}$ Adian Husaini, Islam Liberal, Pluralisme Agama dan Diabolisme Intelektual (Surabaya: Risalah Gusti, 2005) p. 155. 
as a path and not as the goal could endanger the traditionalism itself. This endangerment could happen if we cannot differentiate between what is sacred and profane.

The third object is the law of nature or science. Theosophical Society has tried to combine science and spirituality. If Theosophical Society, on one side, aims to restore spirituality within scientific activities, after the end of the Church, Islam, on the other side, has become the source of a civilization where science developed without a separation between spirituality and science. ${ }^{52}$ The period of the Abbasid Caliphate was the Golden Age of Islamic science and philosophy. ${ }^{53}$ The science here is comprised of objectives, basic premises, objects, and methodologies, as observed by Osman Bakar. ${ }^{54}$

Science, as the path through the globalization of science, has a relationship with Islam. First, science is relevant to Islam. Second, intellectual, cultural, and spiritual advancements can be achieved through science. Third, science will develop continuously, and a similar thing also happens to Theology. Fourth, science will never contradict Islam. ${ }^{55}$

Through brotherhood, Theosophical Society has assembled renowned individuals and huge funds, through media. In Islam, the effects of media can be explained by three arguments. First, media is a powerful tool to destroy morality, which makes it dangerous. Second, the media could spread Islamic

52 Syamsuddin Arif, Sains Di Dunia Islam: Fakta Historis-Sosiologis dalam Institute for The Study of Islamic Thought and Civilization, Islamic Science: Paradigma, Fakta dan Agenda (Jakarta: INSISTS, 2016) p. 83.

53 George Saliba, Islamic Science and the Making of the European Renaissance (Massachusetts: The MIT Press, 2007) p. 2.

54 Osman Bakar, Classification of Knowledge in Islam (Cambridge: The Islamic Texts Society, 1992) p. 5.

${ }^{55}$ Nidhal Guessoum, Islam's Quantum Question (London: I.B. Tauris, 2011) p. xxv. 
values. Third, Muslims, as a community, should have media on their own. ${ }^{56}$ Islam has to be developed, with regards to globalization, to halt doctrines that are different from Islam, and to protect the Muslims. Islam initially is a global, universal religion; thus, Islamic values should be combined with the principles of globalization. ${ }^{57}$ Muhammad is a prophet tasked to spread Islam and to bring mercy to the world as a whole, not only limited to Muslims or even Arabs, as stated in the Quran:

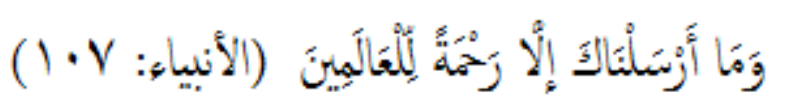

And We have not sent you, [O Muhammad], except as a mercy to the worlds.

\section{Conclusions}

Theosophical Society has three main objects. Those are a global brotherhood, wisdom, spiritualism, or traditionalism, and science. The three objects essentially have global values that could be used to challenge modernistic globalization that has been developed at that time.

Global brotherhood is the first object of the organization, and it also has a vital role in the organization. However, when one's brotherhood became stronger, the faith became weaker. It is evident that the organization bounds their brotherhood within the esoteric domain. In Islam, however, faith covers all domains, including exoteric and esoteric. Therefore, humanity is not enough, as it should be based on faith. The faith itself can be realized through the implementation of the Sharia. The

${ }^{56}$ Andi Faisal Bakti, The Role of Islamic Media in The Globalization Era: Between Religious Principles and Values of Globalization, The Challenges and The Opportunities, p. 2.

57 Andi Faisal Bakti, The Role of Islamic Media in The Globalization Era: Between Religious Principles and Values of Globalization, The Challenges and The Opportunities, p. 2. 
concept of the Theosophical Society is firm; however, for Muslims, the concept is not final and in need of improvement.

Wisdom, traditionalism, and spiritualism is the second object. Through this object, the organization tries to restore local values, either from culture or religion, that have been sidelined by modernistic globalization. The objective of the restoration of the values is ethics. Through ethics, modernism can be controlled, thus preventing it from creating destruction and natural exploitation as in the Middle East, and also human exploitation as in China. In the Islamic perspective, however, traditionalism has the potential to create global relativism. It means that there will be no authority that controls the traditionalist movements. Everyone will be able to create and design their spiritualism. Eventually, traditions will be mixed and lost their originality.

The organization also intends to merge science and spiritualism. In Islamic history, during the reigns of Islamic caliphs, science is not separated from the spiritual, divine values. Therefore, restoring science into spiritualism is a global challenge.

Modernistic globalization that occurred in this century has to be accepted, and it is impossible to reject it. Therefore, in challenging modernistic globalization, creating a balance between it and spiritual values is needed that eventually led to the advancement of both. A similar thing is also possible in Islam; for example, the work of preaching that was once done in local mosques has now done using online media. Through that, Islamic values are protected, and the globalization principles are fulfilled and eventually create individuals that are pious in global and traditional lenses, and knowledgeable in modern and spiritual lenses. 


\section{REFERENCES}

Algeo, John, Theosophy: An Introductory Study Course Wheaton: Theosophical Society, in America, 2007.

Arif, Syamsuddin, Orientalis dan Diabolisme Pemikiran, Jakarta: Gema Insani, 2008.

Sains Di Dunia Islam: Fakta Historis-Sosiologis dalam Institute for The Study of Islamic Thought and Civilization, Islamic Science: Paradigma, Fakta dan Agenda, Jakarta: INSISTS, 2016.

Armas, Adnin, Gagasan Frithjof Schuon tentang Titik-Temu Agama-agama dalam Adnin Armas Ed. Pluralisme Agama: Telaah Kritis Cendekiawan Muslim, Jakarta: Institute for the Study of Islamic Thought and Civilization, 2013.

Bakar, Osman, Classification of Knowledge in Islam, Cambridge: The Islamic Texts Society, 1992. Hal 5.

Bakti, Andi Faisal, The Role of Islamic Media in The Globalization Era: Between Religious Principles and Values of Globalization, The Challenges and The 
Opportunities, makalah yang disampaikan pada The Second International Conference on Islamic Media 13-15 Desember 2011 di Universitas Pancasila.

Besant, Annie, "Theosophical Society" dalam James Hastings, The Encyclopedia of Religion and Ethics, Vol. 12. London: Morrison and Gibb Limited, 1921.

Blavatsky, H.P., The Secret Doctrine, Pasadena, Theosophical University Press Online Edition: 1888. ., The Theosophical Movement California: Cunninghm Press, 1951. ., The Key to Theosophy, Pasadena: Theosophical University Press Online Edition, 1889. ., Theosophy: An Introduction, Blavatsky Study Center, 2012.

Branston, Gill, dan Roy Stafford, The Media Student's Book Third Edition, New York: Routledge, 2003. , dan Roy Stafford, The Media Student's Book Fifth Edition, New York: Routledge, 2010.

Caputo, John D. On Religion, New York: Routledge, 2001.

Dixon, Joy, Divine Feminine, Theosophy and Feminism in England, Maryland: The Johns Hopkins University Press, 2001.

al-Faruqi, Isma'il Raji Al-Tawhid: It's Implications for Thought and Life, Virginia: The International Institute of Islamic Thought, 1992. Hal. 103-104.

Fuller, Graham E., Apa Jadinya Dunia Tanpa Islam, Bandung: Mizan, 2014.

Guenon, Rene, The Crisis of the Modern World, Hillsdale: Sophiaperennis, 1942. 
Guessoum, Nidhal Islam's Quantum Question, London: I.B. Tauris, 2011.

Husaini, Adian, Wajah Peradaban Barat: Dari Hegemoni Kristen ke Dominasi Sekular-Liberal, Jakarta: Gema Insani Press, 2005.

, Islam Liberal, Pluralisme Agama dan Diabolisme Intelektual, Surabaya: Risalah Gusti, 2005.

Lavoie, Jeffrey D., The Theosophical Society: The History of a Spiritualist Movement, Florida: Brown Walker Press, 2012.

Saliba, George, Islamic Science and the Making of the European Renaissance, Massachusetts: The MIT Press, 2007.

Santucci, James A., Theosophy and the Theosophical Societies, Theosophy Forward, 2013.

Steiner, Rudolf, Theosophy, An Introduction to the Supersensible Knowledge of the World and the Destination of Man, Dornach: Rudolf Steiner Press, 2011.

Thoha, Anis Malik Tren Pluralisme Agama, Jakarta: Gema Insani, 2005.

Webster, Hutton, World History, Boston: D.C. Heath \& Co., Publisher, 1921.

Zarkasyi, Hamid Fahmy, Liberalisasi Pemikiran Islam, Ponorogo: Centre for Islamic and Occidental Studies, 2008.

http://www.ts-adyar.org/

http://www.etymonline.com/ 
ابن كثير، أبو الفداء إسماعيل بن عمر، تفسير القرآن العظيم المجلا 7

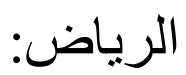

دار الطيبة للنشر و التوزيع، 1997. 